\title{
KONSEP MANAJEMEN INSANI SEBAGAI UPAYA PENINGKATAN KINERJA GURU DI MADRASAH
}

\author{
Supriadi ${ }^{1}$ \\ Kantor Wilayah Kementerian Agama Provinsi Bali \\ supriadiramsin@gmail.com
}

\begin{abstract}
Teachers have their own problems when it comes to deal with their performances quality they have done so far. One of the problems which is clear that some teachers do not really develop themsleves and do reflections to all their performance processes. Teachers' performance improvement actually can be improved by two directions in human management concept, that is leader's and colleague's supports and motivating themselves to do many reflections. The human management concept that is studied in this article is focused on teachers' performance improvement by maximize human potential as the first and main components to improve learning quality and education itself.

Keywords: teacher, human management, performance
\end{abstract}

\begin{abstract}
Abstrak
Para guru memiliki problematika tersendiri ketika bersinggungan dengan kualitas kinerja yang dilakukannya. Salah satu problematika yang tampak adalah kurangnya sebagian guru dalam melakukan pengembangan diri dan refleksi terhadap keseluruhan proses kinerja. Peningkatan kinerja guru sebenarnya bisa dilakukan melalui dua arah pada konsep manajemen insani, yaitu dukungan dari pimpinan dan kolega dan memotivasi diri sendiri dengan melakukan banyak refleksi diri. Konsep manajemen insani yang dikaji pada artikel ini berfokus pada peningkatan kinerja guru dengan memaksimalkan potensi manusia sebagai komponen pertama dan utama dalam meningkatkan kualitas pembelajaran maupun pendidikan itu sendiri.
\end{abstract}

Kata kunci: guru, manajemen insani, kinerja

\section{Pendahuluan}

Pendahuluan artikel ini penulis dahului dengan mengambil quotes dari Maulana Jalaluddin Rumi yang fenomenal secara internasional, yaitu "yesterday I was clever, I wanted to changed the world. Today I am wise, I want to change myself”. Kata-kata mutiara ini sangat berkaitan erat dengan artikel mengenai konsep manajemenen insani, di mana konsep pengembangan dan peningkatan kualitas guru ditentukan oleh pengelolaan insansi atau manusiawi dari guru itu sendiri. Problematika yang sering teramati selama ini dalam dunia kemadrasahan adalah guru sangat termotivasi bahkan berambisi untuk mengubah siswa dan sebuah lembaga menjadi lebih baik. Hal ini sangat baik, namun niat baik

\footnotetext{
${ }^{1}$ Kementerian Agama Provinsi Bali
} 
saja pun tidak cukup. Sesuai dengan quotes Rumi bahwa hal yang paling baik dilakukan adalah dengan mengubah insani manusia itu sendiri, atau jika dikaitkan dengan keguruan, maka guru perlu merubah dirinya melalui perubahan kinerja yang makin baik sehari-harinya.

Dasar dari problematika ini muncul karena guru selalu dituntut untuk menjadi motivator bagi siswanya, namun tidak bagi dirinya sendiri. Tuntutan ini sebenarnya mendewakan seorang guru, bahwa guru selalu termotivasi dalam melaksanakan performancenya. Realitanya, kinerja atau permormance itu sama halnya dengan keimanan yang terkadang naik, terkadang sedang dan terkadang turun, maka daripada itu, konsep pengelolaan diri guru menjadi penting sebagai permulaan untuk meningkatkan kinerja guru dalam pendidikan madrasah.

Guru memang sebagai salah satu komponen pendidikan yang memegang peran penting dalam keberhasilan pendidikan, karena guru diharapkan mampu memainkan peran sebagai guru ideal. Masyarakat mengharapkan guru sebagai sosok yang dapat "digugu dan ditiru”. Guru juga merupakan salah satu tokoh yang harus dijunjung tinggi, yaitu: guru, ratu, wong tuo karo. ${ }^{2}$ Pemerintah sering melakukan berbagai upaya peningkatan kualitas guru, antara lain melalui pelatihan, seminar, dan lokakarya, bahkan melalui pendidikan formal dengan menyekolahkan guru pada tingkat yang lebih tinggi, meskipun pada pelaksanaannya masih belum merata.

Kualitas sebuah pendidikan merupakan salah satu tolok ukur yang menentukan martabat atau kemajuan suatu bangsa. Kualitas tersebut pada suatu bangsa/ negara dapat diperkirakan berdasarkan peringkat negara di dunia, oleh karena itu, bangsa yang maju akan selalu menaruh perhatian besar terhadap dunia pendidikan. Upaya untuk meningkatkan kualitas pendidikan dapat dilakukan dengan berbagai cara, seperti: meningkatkan anggaran pendidikan, menyelenggarakan berbagai lomba dalam berbagai aspek pendidikan, atau mengirimkan para tunas bangsa untuk menimba ilmu di negara lain. Beragam upaya dilakukan karena kesadaran akan pentingnya pendidikan, dan keyakinan bahwa bangsa yang mengabaikan pendidikan akan menjadi bangsa yang tertinggal, serta akan kalah bersaing dengan bangsa-bangsa lain.

Rendahnya kualitas pendidikan di Indonesia merupakan salah satu dari empat masalah pokok pendidikan yang telah diidentifikasi sejak tahun 60-an. Perhatian terhadap pendidikan memang cukup besar, namun meskipun sudah banyak usaha yang dilakukan, sampai sekarang masalah ini tampaknya belum dapat diatasi secara maksimal. Keluhan tentang rendahnya mutu output masih terus meningkat.

2 H.A.R. Tilaar, Paradikama Baru Pendidikan Nasional (Jakarta: Rineka Cipta, 2004), 89 
Lulusan SD, SLTP, dan SLTA belum mampu bernalar dan berpikir kritis, serta masih tergantung kepada guru. ${ }^{3}$ Kemampuan siswa untuk mandiri belum terwujud secara menyeluruh, sehingga prakarsa siswa untuk memulai sesuatu tidak terlampau sering ditemukan. Penguasaan siswa lebih terfokus pada pengetahuan faktual, karena hal itulah yang dituntut dalam ujian akhir. Penyebab dari semua ini sangat banyak, tetapi seringkali penyebab tersebut diperkirakan kepada guru, karena guru merupakan ujung tombak di lapangan yang bertemu dengan siswa secara terprogram. Guru dianggap sebagai pihak yang paling bertanggung jawab terhadap hasil yang dicapai oleh siswa. ${ }^{4}$

Berbagai upaya telah dilakukan dalam peningkatan kinerja guru untuk menjawab tantangan tersebut. Penataran-penataran guru yang dilakukan secara berkala maupun secara berkesinambungan telah dilakukan. Kesejahteraan guru, yang merupakan hal sensitif namun penting juga sudah mulai diperhatikan, meskipun dalam skala yang masih kurang. Pemberian insentif bagi guru yang mengajar di daerah terpencil dan pemberian tunjangan fungsional bagi guru telah diprogramkan. Selain upaya yang secara khusus dilakukan untuk meningkatkan kemampuan profesional dan kesejahteraan guru, upaya yang sangat penting adalah upaya untuk meningkatkan kualifikasi guru yang telah dilakukan dari masa ke masa.

Proses pembelajaran di madrasah serta kualitasnya sangatlah tergantung pada tingkat kinerja guru. Peningkatan mutu pendidikan berbasis madrasah tidak mungkin ada tanpa kinerja guru yang profesional. ${ }^{5}$ Proses belajar mengajar merupakan interaksi edukatif yang dilakukan oleh guru dan siswa dalam situasi tertentu. Proses belajar mengajar bukanlah suatu pekerjaan yang mudah dan dapat terjadi begitu saja tanpa direncanakan sebelumnya, akan tetapi mengajar merupakan suatu kegiatan yang semestinya direncanakan dan didesain sedemikian rupa mengikuti langkah-langkah dan prosedur tertentu hingga pelaksanaannya dapat mencapai hasil yang diharapkan. ${ }^{6}$

Upaya-upaya terbaik telah dilakukan oleh Sang Pendidik, sehingga dapat meningkatkan kualitas madrasah dan melahirkan anak didik yang berkualitas. Upaya-upaya tersebut perlu didukung dengan sebuah konsep yang tepat dan sesuai dengan sistem kemadrasahan yang ada. Konsep manajemen insani ini bisa menjadi pengarah dalam mendapatkan konsep yang tepat, karena konsep ini

\footnotetext{
${ }^{3}$ M.N. Nasution, Manajemen Mutu Pendidikan (Bogor: Ghalia Indonesia, 2005), 1

4 Winardi, Manajemen Perubahan (Jakarta: PT. Raja Grafindo Persada, 2005), 205

${ }^{5}$ Ibrahim Bafadal, Peningkatan Profesionalisme Guru Sekolah Dasar (Jakarta: Bumi Askara, 2004), 4

${ }^{6}$ Syafrudin Nurdin, Guru Profesional dan Implementasi Kurikulum (Jakarta: Ciputat Pers, 2002), 8

78 | Jurnal Auladuna
} 
didasarkan pada paradigma dengan perspektif Al-Qur'an, sehingga diharapkan mampu memberikan pemecahan masalah pada insani pada guru-gur madrasah dalam peningkatan kinerjanya.

\section{Pembahasan}

\section{Pengertian Kinerja Guru}

Kinerja merupakan terjemahan dari kata performance (job performance) yang secara etimologis, performance berasal dari kata to perform yang berarti menampilkan atau melaksanakan. Kata performance berarti "the act of performing; execution", menurut Henry Bosley Woolf, performance berarti "the execution of an action". Kinerja atau performance merupakan tindakan menampilkan atau melaksanakan suatu kegiatan, oleh karena itu performance sering diartikan sebagai penampilan kerja atau perilaku kerja. ${ }^{7}$ Kinerja adalah sesuatu yang dicapai atau prestasi yang diperlihatkan atau kemampuan bekerja seseorang, kinerja dapat diartikan sebagai prestasi kerja. Kinerja atau performance merupakan hasil kerja yang dapat dicapai oleh seseorang atau sekelompok orang dalam suatu organisasi, sesuai dengan wewenang dan tanggung jawab masing-masing. Upaya yang dimaksud adalah mencapai tujuan organisasi tersebut secara legal, tidak melanggar hukum, dan sesuai dengan moral maupun etika.

Guru adalah tenaga profesional dibidang kependidikan dengan tugas mengajar, mendidik, dan membimbing anak didik agar menjadi manusia yang berkepribadian (pancasila). ${ }^{8}$ Pandangan tradisional menyematkan guru sebagai orang yang berdiri di depan kelas untuk menyampaikan ilmu pengetahuannya. Departemen Pendidikan dan Kebudayaaan mengartikan guru sebagai seorang dengan gagasan yang harus diwujudkan untuk kepentingan anak didik, sehingga menunjang hubungan sebaik-baiknya dengan anak didik, yang dampaknya mampu menjunjung tinggi, mengembangkan, dan menerapkan keutamaan menyangkut agama, budaya dan keilmuan.

Guru sebagai ukuran kognitif secara umum adalah bertugas mewariskan pengetahuan dan berbagai keterampilan kepada generasi muda. Hal-hal yang akan diwariskan itu sudah tentu harus sesuai dengan ukuran-ukuran yang telah ditentukan oleh masyarakat dan merupakan gambaran tentang keadaan sosial, ekonomi, dan politik masyarakat bersangkutan. Seorang guru harus

${ }^{7}$ Uhar Saputra, Pengembangan Kinerja Guru, http://uharsputra.wordpress.com/pendidikan/pengembangan-kinerjaguru/diakses pada Tanggal 29 November 2020

8 A.M. Sudirman, Interaksi dan Motivasi Belajar Mengajar (Jakarta: Raja Grafindo, 2006), 125

${ }^{9}$ Syafruddin Nurdin, Guru Profesional dan Implementasi Kurikulum ..., 8 
memenuhi ukuran kemampuan yang diperlukan untuk melaksanakan tugasnya, sehingga anak dapat mencapai ukuran pendidikan secara maksimal.

Kinerja guru adalah hasil kerja yang dapat dicapai oleh seorang guru di lembaga pendidikan atau madrasah sesuai dengan tugas dan tanggung jawabnya dalam mencapai tujuan pendidikan. Hasil kerja yang dicapai seseorang dalam melaksanakan tugas-tugas yang dibebankan kepadanya didasarkan atas kecakapan, pengalaman, dan kesungguhannya. Kinerja dikatakan baik dan memuaskan apabila tujuan yang dicapai sesuai dengan standar yang telah ditetapkan.

Para guru perlu memiliki tiga kemampuan dasar agar kinerjanya tercapai, sebagai berikut: ${ }^{10}$

1. Kemampuan pribadi meliputi hal-hal yang bersifat fisik, seperti: tampang, suara, mata atau pandangan, kesehatan, pakaian, pendengaran, dan hal yang bersifat psikis, seperti: humor, ramah, intelek, sabar, sopan, rajin, kreatif, kepercayaan diri, optimis, kritis, objektif dan rasional.

2. Kemampuan sosial, antara lain: bersifat terbuka, disiplin, berdedikasi, tanggung jawab, suka menolong, bersifat membangun, tertib, adil, pemaaf, jujur, demokratis dan cinta anak didik.

3. Kemampuan profesional yang meliputi 10 kemampuan profesional guru yaitu:

a. Menguasai bidang studi dalam kurikulum sekolah dan menguasai bahan pendalaman/ aplikasi bidang studi.

b. Mengelola program belajar mengajar.

c. Mengelola kelas.

d. Menggunakan media dan sumber.

e. Menguasai landasan-landasan kependidikan, mengelola interaksi belajar mengajar.

f. Menilai prestasi siswa untuk kepentingan pendidikan.

g. Mengenal fungsi dan program bimbingan penyuluhan.

h. Mengenal dan menyelenggarakan administrasi sekolah.

i. Memahami prinsip.

j. Menafsirkan hasil-hasil penelitian pendidikan guna keperluan mengajar.

Kinerja guru adalah persepsi guru terhadap prestasi kerja guru yang berkaitan dengan kualitas kerja, tanggung jawab, kejujuran, kerja sama dan prakarsa. Kompensasi yang diberikan kepada guru sangat berpengaruh pada tingkat kepuasan kerja, motivasi kerja, dan hasil kerja. Kompensasi yang

10 Muhammad Fathurrohman, Implementasi Manajemen Peningkatan Mutu Pendidikan Islam (Yogyakarta: Teras, 2012 ), 29 80 | Jurnal Auladuna 
diberikan dengan mempertimbangkan standar kehidupan normal guru dan dapat memenuhi kebutuhan-kebutuhan guru, maka dengan sendirinya akan mempengaruhi semangat kerjanya dan akan meningkatkan kualitas setiap pekerjaan yang dilakukan, karena tujuan bekerja guru banyak dipengaruhi oleh terpenuhi atau tidaknya kebutuhan minimal kehidupan guru dan keluarganya. Dampaknya adalah meningkatnya perhatian guru secara penuh terhadap profesi dan pekerjaanya, maka jika kompensasi yang diberikan makin besar, kepuasan kerjanya makin membaik.

\section{Faktor-faktor Peningkat Kinerja Guru}

Faktor-faktor yang mempengaruhi kinerja guru pada dasarnya sangat beragam, termasuk kesadaran guru itu sendiri, namun beberapa faktor eksternal yang dominan antara lain: peran kepemimpinan kepala sekolah, pemberian kompensasi, kedisiplinan guru, dan pengembangan Sumber Daya Guru (SDM).

Faktor-faktor yang mempengaruhi kinerja guru jika diidentifikasi satu-persatu terdiri dari: ${ }^{11}$

1. Faktor personal/ individual, meliputi unsur pengetahuan, keterampilan (skill), kemampuan, kepercayaan diri, motivasi dan komitmen yang dimiliki oleh tiap individu guru.

2. Faktor kepemimpinan, meliputi aspek kualitas manajerial dan team leader dalam memberikan dorongan, semangat, arahan dan dukungan kerja pada guru.

3. Faktor tim, meliputi kualitas dukungan dan semangat yang diberikan oleh rekan dalam satu tim, kepercayaan terhadap sesama anggota tim, kekompakan dan keeratan anggota tim.

4. Faktor sistem, meliputi sistem kerja, fasilitas kerja yang diberikan oleh pimpinan madrasah, proses organisasi madrasah dan kultur kerja dalam organisasi madrasah.

\section{Indikator-indikator Kinerja Guru}

Penialain kualitas kinerja dapat ditinjau dari beberapa indikator, meliputi: 1) unjuk kerja; 2) penguasaan materi; 3) penguasaan profesional keguruan dan pendidikan; 4) penguasaan cara-cara penyesuaian diri; dan (5) kepribadian untuk melaksanakan tugasnya dengan baik. Kinerja guru sangat penting untuk diperhatikan dan dievaluasi, karena guru mengemban tugas profesional yang artinya tugas-tugas tersebut hanya dapat dikerjakan dengan kompetensi khusus yang diperoleh melalui program pendidikan. Indikator-indikator kinerja guru dapat diuraikan sebagai berikut:

${ }^{11}$ Ibid., 91 
1. Kemampuan membuat perencanaan dan persiapan mengajar.

2. Penguasaan materi yang akan diajarkan kepada siswa.

3. Penguasaan metode dan strategi mengajar.

4. Pemberian tugas-tugas kepada siswa.

5. Kemampuan mengelola kelas.

6. Kemampuan melakukan evaluasi.

Perencanaan pengajaran menjadi sangat penting dan sebagai salah satu indikator utama, yaitu bagaimana cara mendesain suatu program yang akan dilakukan, dan pola mengajar apa yang akan diterapkan sehubungan dengan pelaksanaan program yang telah di desain tersebut. Perencanaan pembelajaran juga merupakan suatu rencana untuk mengerjakan prosedur dan merancang sesuatu secara efisien. Kehadiran perencanaan pembelajaran akan mampu menilai suatu kemungkinan yang dapat tersampaikan dalam langkah-langkah untuk mencapai tujuan sistem yang telah ditetapkan. ${ }^{12}$ Pengertian perencanaan menurut William H. Newman adalah menentukan apa yang akan dilakukan. ${ }^{13}$ Perencanaan tersebut berisikan rangkaian-rangkaian keputusan luas dan penjelasan-penjelasan tentang tujuan, penentuan kebijakan, penentuan program, penentuan metode-metode, dan prosedur tertentu serta penentuan kegiatan berdasarkan jadwal dari perencanaan itu sendiri.

Materi pembelajaran merupakan salah satu sumber belajar berisi pesan dalam bentuk konsep, prinsip, definisi, gugus isi atau konteks, data maupun fakta, proses, nilai, kemampuan dan keterampilan. Materi yang dikembangkan guru hendaknya mengacu pada kurikulum yang terdapat dalam silabus dengan pencapaian tujuan disesuaikan kebutuhan dan lingkungan siswa. Materi pokok juga merupakan operasionalisasi atau penjabaran dari kompetensi dasar/ inti, serta indikator berfungsi untuk memudakan penetapan materi pembelajaran.

Metode pembelajaran dapat diartikan benar-benar sebagai metode, tetapi dapat pula diartikan sebagai model atau pendekatan pembelajaran, tergantung pada karakteristik pendekatan atau strategi yang dipilih. Guru perlu memahami berbagai macam metode yang digunakan, sehingga mempermudah guru dalam memilih metode yang tepat dengan situasi dan kondisi siswa.

Evaluasi lebih banyak dilakukan terhadap hasil yang dicapai siswa, yaitu dengan membandingkan hasil evaluasi awal dan hasil evaluasi akhir. Evaluasi juga berfungsi untuk melihat

12 Ibid., 19

13 Abdul Majid, Perencanaan Pembelajaran: Mengembangkan Standar Potensi Guru (Bandung: Rosda Karya, 2007), 15

82 | Jurnal Auladuna 
efektivitas program pengajaran, cara yang paling banyak dilakukan ialah melalui tes yang diberikan pada awal dan akhir program. Makin besar perbedaan hasil tes awal dan tes akhir, maka makin efektif program pembelajaran yang bersangkutan.

Pengevaluasian pembelajaran atau penilaian adalah penerapan berbagai cara dan penggunaan beragam alat penilaian untuk memperoleh informasi sejauh mana hasil belajar siswa dapat mencapai kompetensi minimal yang telah ditentukan. ${ }^{14}$ Penilaian menjawab pertanyaan tentang sebaik apa hasil atau prestasi belajar seorang siswa. Berkaitan dengan hal ini, guru harus membuat keputusan mengenai pencapaian belajar kompetensi dari siswa. Evaluasi juga merupakan suatu proses yang terus-menerus, bukuan hanya pada akhir pengajaran, tetapi dimulai sebelum dilaksanakannya pengajaran sampai pada berakhir pengajaran ${ }^{15}$ Proses evaluasi senantiasa diarahkan ke tujuan tertentu, yakni mendapatkan jawaban-jawaban tentang bagaimana memperbaiki pengajaran dan kinerja guru itu sendiri.

\section{Upaya Peningkatan Kinerja Guru Madrasah Melalui Konsep Manajemen Insani Pemberian Motivasi Berparadigma Al-Qur'an}

Motivasi (alquwwab) memiliki peranan penting bagi seseorang untuk melakukan sesuatu. Jika diartikan sebagai sebuah "niat" yang hampir dekat dengan arti kata "motif', kemungkinan besar alquwwah ini merupakan akar dari segala perbuatan manusia. Motivasi dalam Kamus Besar Bahasa Indonesia diartikan sebagai dorongan yang timbul pada diri seseorang secara sadar atau tidak sadar untuk melakukan suatu tindakan dengan tujuan tertentu. ${ }^{16}$ Kamus Merriam-Webster mengartikan dengan the act of process of motivating dan the condition of being motivated. ${ }^{17}$ Pengertian-pengertian tersebut menunjukkan sebenarnya motivasi memainkan peranan sangat penting bagi seseorang dalam melakukan performancenya, karena tanpa adanya motif ini, seseorang tidak akan memaksimalkan apa yang sedang dikerjakan.

Motivasi dapat diartikan sebagai keadaan internal seseorang, baik berupa keinginan, kebutuhan dan kekuatan yang mendorongnya untuk melakukan suatu aktivitas kerja. Seorang manajer pendidikan lembaga pendidikan harus mengetahui dan membina motivasi para rekan sejawatnya,

\footnotetext{
${ }_{14}$ Harmi Hendra, Perencanaan Sistem Pembelajaran: Kurikulum Tingkat Satuan Pendidikan (Curup: LP2 STAIN, 2010$), 145$

15 Oemar Hamalik, Perencanaan Pembelajaran Berdasarkan Pendekatan Sistem (Jakarta: Bumi Aksara, 2003), 210

${ }^{16}$ Kamus Besar Bahasa Indonesia elektronik

${ }^{17}$ Merriam-Webster Electronic Dictionary
} 
sebab terdapat hasil penelitian dari para ahli bahwa motivasi yang ada dalam diri seorang rekan sejawat terkait pekerjaannya akan mempengaruhi tingkat kinerja dan produktivitas Sang Guru. ${ }^{18}$

Al-Qur'an pun juga membahas tentang bagaimana seorang khalifah yang artiannya dalam kajian ini adalah pemimpin madrasah memberikan dorongan kepada para tenaga pendidik di bawah koordinasinya dengan melakukan beberapa teknik yang bisa diterapkan, yaitu: ${ }^{19}$

\section{Memenuhi kebutuhan tenaga pendidik}

Allah adalah $A$-Razzaq, yang berasal dari kata razaqa dengan arti dasar "pemberian untuk waktu tertentu", kemudian dari makna rezeki itu berkembang dan diartikan sebagai pangan, pemenuhan kebutuhan, gaji, hujan, dan bahkan anugerah kenabian pun dapat dinamai sebagai rezeki. Al-Razzaq adalah Allah yang mengulang-ulang dan banyak sekali memberi rezeki kepada makhluk-makhluknya, pernyataan ini ditegaskan oleh Quraish Shihab dalam tulisannya.

Sebagai seorang manajer pendidikan madrasah, sudah seharusnya mengetahui kebutuhan-kebutuhan pegawainya, karena tenaga pendidik memiliki kebutuhan-kebutuhan yang harus dipenuhi. Apabila kebutuhan-kebutuhan tersebut terpenuhi, maka motivasi para guru dalam menjalankan tugas dan tanggung jawabnya akan meningkat dan akan mempengaruhi kinerja guru.

\section{Memberikan pujian atau tanggapan positif}

Sejarah Islam menuliskan kisahnya bahwa Rasulullah telah memberikan contoh bagaimana membangkitkan motivasi para sahabatnya melalui pemberian pujian. Beliau memberikan gelar-gelar kepada para sahabat sesuai dengan keahlian atau kelebihan yang dimilikinya. Conto kecil yang bisa kita lihat adalah, setelah Perang Uhud, Rasulullah memuji para sahabtnya dengan ungkapan "sebaik-baik penunggang kuda kita adalah Abu Qatadah dan sebaik-baik pejalan kaki adalah Salamah".

Seorang manajer madrasah harus memahami kenyataan bahwa setiap orangsuka untuk dipuji, sehingga Sang Manajer tersebut tidak akan segan memberikan pujian kepada pegawainya. Pujian merupakan sebuah pengakuan terhadap sebuah kinerja yang bagus. Cara yang bisa digunakan dalam memberikan pujian adalah: 1) memulai dengan bidang kinerja yang ingin dipuji; 2) memberikan suatu contoh spesifik tentang kinerja seseorang; 3) menyebutkan beberapa

\footnotetext{
${ }^{18}$ Abdus Salam, Manajemen Insani dalam Pendidikan (Yogyakarta: Pustaka Pelajar, 2014), 250
}

${ }^{19}$ Ibid., 259-266

84 | Jurnal Auladuna 
kualitas personal; 4) memberikan komentar mengenai sisi positif prestasi yang merupakan tujuan tim secara keseluruhan.

Pujian yang diberikan seorang pemimpin kepada pegawainya dapat mengoptimalkan potensi kelompok kerja dalam melakukan tugas. Pemikiran ini sepadan dengan yang dikatakan oleh Rupert Eales-White bahwa pemberian pujian diakui dapat membangun motivasi para pegawai. Seorang manajer madrasah sebaiknya menjauhkan diri dari perkataan yang mengandung “celaan” kepada tenaganya, sebab dengan celaan tidak akan memberikan apa-apa, baik kepada diri manajer/ pemimpin tersebut maupun kepada para pegawainya. Pujian merupakan bentuk apresiasi terhadap kinerja orang lain. Pujian adalah cara yang efektif dalam membangun semangan kerja para pegawan (menurut Ahmad Abdul Jawwad).

\section{Memberikan penghargaan (rewards) dan hukuman (punishment)}

Konsep rewards dan punishment dalam Islam dapat ditelusuri dari konsep basyir dan nadzir. Basyir adalah pemberian kabar gembira kepada orang yang melakukan amal shaleh (berprestasi), sementara nadzir adalah pemberian peringatan atau hukuman kepada orang-orang yang melanggar perintah Allah. Al-Qur'an banyak mengandung isyarat tentang penghargaan dan hukuman. Allah menjanjikan dalam berbagai ayat pahala berlipat ganda atau kehidupan yang baik, baik di dunia maupun di surga sebagai balasan terhadap orang yang beriman dan melakukan amal kebaikan di dunia. Allah juga memberikan ancaman kepada siapa saja yang melakukan pelanggaran terhadap hukum-hukumnya, baik berupa kehidupan yang sempit di dunia, atau pun siksaan neraka di akhirat kelak.

Pemberian motivasi kepada pegawai memerlukan penerapan konsep ini, penghargaan dan hukuman. Keduanya merupakan kesatuan yang tak terpisahkan, dan harus mendapat perhatian secara seimbang. Apabila hanya penghargaan yang diperhatikan, maka para pegawai dalam melakukan pekerjaan hanya untuk meraih tujuan jangka pendek. Sementara bila perhatiannya hanya tertuju pada pemberian hukuman, maka bisa jadi akan membuat para pegawai tidak berkembang, karena mereka berada dalam ketakutan.

Pemberian hukuman ini harus diperhatikan mekanismenya. Mekanisme pemberian hukum menurut Hafidhuddin harus jelas. Suatu hukuman baru bisa diterapkan setelah sebelumnya diberikan peringatan kepada pegawai yang melakukan pelanggaran.

\section{Membangkitkan motivasi dengan kisah}


Al-Qur'an menyatakan bahwa kisah dapat dijadikan sebagai pelajaran (i'tibar) bagi orangorang yang mau dan memiliki kemampuan untuk mempelajarinya. Kisah bisa dijadikan sebagai salah satu cara yang bisa digunakan oleh seorang manajer madrasah dalam rangka membangkitkan motivasi kerja para rekannya. Seorang manajer madrasah bisa menceritakan sejarah orang-orang sukses kepada para rekannya. Dari kisah itu, mereka dapat belajar mengenai faktor-faktor yang menyebabkan mereka meraih kesuksesan dalam pekerjaannya, dengan demikian para pegawai akan termotivasi untuk meraih kesuksesan yang sama.

\section{Prinsip-prinsip Manajemen Insani Perspektif Al-Qur'an}

Al-Qur'an memberikan keterangan dan penjelasan mengenai prinsip-prinsip apa saja yang perlu dianut oleh para tenaga pendidik dalam menjalankan tugasnya agar kinerja pengajaran dan pembelajarannya tetap terjaga secara kualitas. Prinsip-prinsip manajemen insani yang diajarkan oleh Al-Qur'an antara lain: ${ }^{20}$

1. Prinsip taubid; seorang guru madrasah harus teguh dalam akidah (taubid) dan konsisten dalam syari'at Islam, serta memiliki komitmen dalam menerapkan nilai-nilai Islam ke dalam seluruh aktivitas dan aspek kehidupannya, baik ekonomi, politik, budaya, seni maupun pendidikan.

2. Prinsip kesatuan arah; seluruh aktivitas kependidikan harus mengacu kepada prinsip ikhlas beramal, yang mana seorang guru dalam menjalankan tugas dan tanggung jawabnya harus didasarkan dalam rangka beribadah kepada Allah.

3. Prinsip kesatuan komando; seluruh aktivitas manajemen insani harus berada di bawah instruksi seorang pimpinan. Setiap tenaga pendidik harus menerima perintah/ instruksi dari satu orang pimpinan atau atasannya. Penerapan prinsip ini menghendaki tidak adanya dualisme dalam pemberian tugas dan wewenang.

4. Prinsip keadilan dan kesejabteraan; penerapan prinsip ini dimulai dari penyusunan organisasi atau lembaga pendidikan, pembagian departemen atau pembagian divisi tugas, penempatan tenaga kependidikan sesuai prinsip-prinsip profesionalisme, sampai kepada pemenuhan hak-hak pegawai, baik hal sosial atau individunya, seperti masalah penggajian dan penerapan sanksi bagi yang melanggar.

${ }^{20}$ Ibid., 59-94

86 | Jurnal Auladuna 
5. Prinsip musyawarab; penerapan prinsip ini dilakukan dengan cara melibatkan seluruh komponen organisasi dalam pengambilan keputusan organisasi. Setiap tenaga pendidik memiliki kewajiban yang sama untuk mewujudkan tujuan organisasi atau lembaga, termasuk mereka memiliki hak dan kebebasan untuk mengemukakan pendapat.

6. Prinsip efisiensi, efektivitas dan produktivitas kerja; prinsip ini memungkinkan guru untuk seefektif dan efisien mungkin dalam merencanakan tugas dan pekerjaan secara sistematis seuai dengan instruksi pimpinan madrasah.

7. Prinsip disiplin, integritas dan loyalitas; unsur-unsur pada prinsip ini terdiri dari kewibawaan dan keteladanan seorang pemimpin, konsisten dan melakukan pengawasan.

8. Prinsip pembagian wewenang dan tanggung jawab; pemimpin mengembangkan kemampuankemampuan yang tersimpan pada diri seorang guru, yang mana mereka harus mendapatkan wewenang dan tanggung jawab sesuai dengan keahlian yang dimilikinya, sehingga guru tersebut dapat memiliki kebebasan untuk mengembangkan diri sesuai dengan wilayah tanggung jawab yang diterimanya.

9. Prinsip ukhuwah; semua pegawai atau tenaga pendidik adalah sama, persamaan itu adalah tujuan bersama yang ingin dicapai, sehingga rasa persaudaraan perlu ditanamkan pada prinsip ini.

\section{Peran Kepemimpinan Madrasah}

Kepala madrasah sebagai pimpinan top level management berperan penting dalam memegang kunci keberhasilan. Kepala sekolah harus kompeten untuk mewujudkan harapan yang secara umum harus memiliki pengetahuan, keterampilan, sikap, kinerja, dan etika kerja sesuai dengan tugas dan tanggung jawabnya sebagai kepala madrasah. Kepala sekolah juga harus memiliki jiwa kepemimpinan sesuai dengan konsep dari Ki Hajar Dewantara, yaitu: "Ing ngarsa sung tuladha, ing madya mangun karsa, tut wuri handayani". 21

Tugas kepala madrasah sebagai manajer adalah melaksanakan fungsi-fungsi manajemen yang berupa perecanaan, pengorganisasian, pelaksanaan dan mengevaluasi kinerja guru. Kepala madrasah menyusun kinerja guru dengan melibatkan semua unsur personalia madrasah. Manajemen sumber daya manusia diterapkan oleh kepala madrasah atau dalam istilah manajemennya adalah manajer telah direspon oleh tenaga pendidik sehingga mereka memiliki rasa tanggung jawab dan secara profesionalisme telah melaksanakan tanggung jawab atau tugas yang dibagikan (job description). Kepala madrasah perlu

${ }^{21}$ E. Mulyasa, Menjadi Kepala Sekolah Profesional (Bandung: Remaja Rosda Karya, 2004), 19 
memberikan training kepada guru dalam peningkatan kinerjanya dengan mengajarkan kemandirian agar problematika yang ditemui selama bekerja tidak selalu dikonsultasikan kepada kepala madrasah.

Kepala madrasah merupakan salah satu komponen pendidikan berpengaruh dalam meningkatkan kinerja guru. Kepala madrasah bertanggung jawab atas penyelenggaraan kegiatan pendidikan, administrasi sekolah, pembinaan tenaga kependidikan, dan pendayagunaan serta pemeliharaan sarana dan prasarana. Hal-hal tersebut menjadi lebih penting sejalan dengan makin kompleksnya tuntutan tugas kepala madrasah yang menghendaki dukungan kinerja makin efektif dan efisien.

\section{Kedisiplinan Guru}

Disiplin adalah kesadaran dan kesediaan seseorang menaati semua peraturan lembaga dan norma-norma sosial yang berlaku. Arti kesadaran adalah sikap seseorang secara sukarela menaati semua peraturan dan sadar akan tugas serta tanggung jawabnya, sedangkan arti kesediaan adalah suatu sikap, tingkah laku, dan perbuatan seseorang sesuai dengan peraturan lembaga baik tertulis maupun tidak. Davis menjelaskan jika disiplin kerja dapat diartikan sebagai pelaksanaan manajemen untuk memperteguh pedoman-pedoman sebuah organisasi. ${ }^{22}$

Disiplin pada hakikatnya adalah kemampuan untuk mengendalikan diri dalam bentuk tidak melakukan sesuatu tindakan yang tidak sesuai dan bertentangan dengan sesuatu yang telah ditetapkan, dan melakukan sesuatu yang mendukung dan melindungi dari sesuatu yang telah ditetapkan. Kaitannya dalam kehidupan sehari-hari dikenal dengan disiplin diri, disiplin belajar, dan disiplin kerja. Disiplin kerja merupakan kemampuan seseorang untuk secara teratur dan tekun terusmenerus serta bekerja sesuai dengan aturan-aturan yang berlaku dengan tidak melanggar aturanaturan yang sudah ditetapkan.

Rasa ketaatan terhadap peraturan-peraturan lembaga akan timbul dengan sendirinya melalui disiplin, namun tetap, pengawasan terhadap pelaksanaan disiplin tersebut perlu dilakukan. Disiplin kerja adalah persepsi guru terhadap sikap pribadi guru mengenai ketertiban dan keteraturan diri yang dimiliki oleh guru dalam bekerja di madrasah tanpa ada pelanggaran-pelanggaran yang merugikan dirinya, orang lain, atau lingkungannya. Uraian-uraian tersebut menghasilkan beberapa poin penting, antara lain:

${ }^{22}$ Hasibun, 212

88 | Jurnal Auladuna 
1. Disiplin terhadap tugas kedinasan, meliputi: mentaati peraturan kerja, menyiapkan kelengkapan mengajar dan melaksanakan tugas-tugas pokok.

2. Disiplin terbadap waktu, meliputi: menepati waktu mengajar, memanfaatkan waktu dengan baik dan menyelesaikan tugas tepat waktu.

3. Disiplin terhadap suasana kerja, meliputi: memanfaatkan lingkungan sekolah, menjalin hubungan baik dan menjaga keseimbangan antara hak serta kewajiban.

4. Disiplin melayani orang lain, meliputi: melayani peserta didik, melayani orang tua siswa dan melayani masyarakat sekitar.

5. Disiplin sikap dan tingkah laku, meliputi: memperhatikan sikap, menjaga tingkah laku dan memperhatikan harga diri.

\section{Pengembangan SDM Insani}

Upaya meningkatkan kualitas pendidikan membutuhkan waktu yang panjang, serangkaian proses teratur dan sistematis harus dilakukan, karena terkait dengan berbagai aspek kehidupan bangsa. Kualitas pendidikan tersebut perlu disesuaikan dengan perkembangan zaman. Perkembangan zaman yang makin pesat membawa perubahan alam pikir manusia, termasuk di dalamnya perubahan paradigma dalam meningkatkan kualitas pendidikan. Pengembangan kualitas Sumber Daya Manusia (SDM) sebagai suatu proses pembudayaan bangsa, bertujuan untuk meningkatkan kualitas manusia Indonesia yang menguasai pengetahuan, keterampilan, keahlian, serta wawasan sesuai dengan perkembangan iptek.

Sumber daya manusia berperan besar bagi kesuksesan suatu organisasi pendidikan. Manajer merancang dan membuat sebuah organisasi dengan harapan dapat bertahan dan berhasil mencapai tujuan. Manajemen sumber daya manusia merupakan salah satu bidang dari manajemen umum yang meliputi: 1) segi-segi perencanaan; 2) pengorganisasian; 3) pelaksanaan; 4) pengendalian. Guru adalah kondisi yang diposisikan sebagai garda terdepan dan posisi sentral di dalam pelaksanaan proses pembelajaran, maka, guru akan menjadi bahan pembicaraan banyak orang, dan tentunya tidak lain berkaitan dengan kinerja guru. Kesimpulannya, bahwa manajemen sumber daya manusia diakui sangat penting, karena setiap guru memiliki kinerja yang perlu dikembangkan dan dikelola secara periodik.

Pengembangan sumber daya manusia merupakan suatu kebutuhan yang harus dilakukan secara terus menerus. Persaingan yang ketat antar lembaga pendidikan merupakan tantangan yang makin 
berat. Peningkatan kualitas sumber daya manusia (guru) menjadi pilihan utama dan pertama untuk menghadapi persaingan ketat tersebut. Sumber daya manusia sangat berperan dalam menentukan kemajuan suatu lembaga pendidikan. Fasilitas dan sarana prasarana serta dana menjadi unsur penunjang kemajuan sebuah lembaga pendidikan. Pada dasarnya terdapat banyak sumber daya dalam manajemen yang terlibat pada sebuah lembaga pendidikan, antara lain: manusia, sarana-prasarana, biaya, teknologi dan informasi. Sumber daya manusia sebagai komponen utama dan pertama tetap merupakan yang paling penting dalam perjalanan pendidikan. Sumber daya manusia akan menunjang madrasah dengan berbagai kemampuan, karya, bakat, kreativitas dan semangat diri. Aspek teknologi dan ekonomi tanpa aspek manusia dirasa sulit untuk mencapai tujuan-tujuan yang telah ditetapkan.

Guru adalah kondisi yang diposisikan sebagai garda terdepan dan posisi sentral dalam pelaksanaan proses pembelajaran. Kualitas seorang guru dilihat dari kinerja dan totalitas, dedikasi dan loyalitas pengabdiannya. Guru yang merupakan salah satu unsur di bidang kependidikan harus berperan secara aktif dan menempatkan kedudukannya sebagai tenaga profesional, sesuai dengan tuntutan masyarakat yang makin berkembang. Guru tidak semata-mata sebagai pengajar yang melakukan transfer ilmu pengetahuan, tetapi juga sebagai pendidik yang melakukan transfer nilai, sekaligus sebagai pembimbing dengan memberikan pengarahan dan menuntun siswa dalam belajar.

\section{Penutup}

Manajemen insani merupakan hal proses pengelolaan sebuah kualitas pendidikan melalui peningkatan kualitas manusianya itu sendiri. Manajemen ini berlandaskan pada nilai-nilai agama yang lebih berfokus pada ajaran-ajaran yang terdapat di dalam Al-Qur'an. Cara-cara pengelolaan insani yang dilakukan mengarah pada nilai-nilai Islam itu sendiri, karena peningkatan kinerja untuk guru nantinya akan berlangsung dalam jangka panjang dibandingkan tanpa adanya nilai-nilai Islam yang tertanam pada pengelolaannya.

Fokus manajemen insani dengan cara memberikan motivasi, menjalankan prinsip-prinsipnya, mengutamakan peran pemimpin madrasah, mendisiplinkan diri dan mengembangkan sumber daya diri atau sumber daya manusia itu sendiri. Manajemen insani ini tidak hanya dilakukan oleh guru secara perorangan dalam meningkatkan kinerjanya, namun juga membutuhkan dorongan-dorongan lain dari kolega dan pimpinan madrasah agar peningkatan kinerja bisa maksimal.

\section{Referensi}

90 | Jurnal Auladuna 


\begin{tabular}{|l|l|}
\hline 1 & Tilaar, H.A.R. 2004. Paradikama Baru Pendidikan Nasional. Jakarta: Rineka Cipta. \\
\hline 2 & Nasution, M.N. 2005. Manajemen Mutu Pendidikan. Bogor: Ghalia Indonesia. \\
\hline 3 & Winardi. 2005. Manajemen Perubahan. Jakarta: PT. Raja Grafindo Persada. \\
\hline 4 & Bafadal, I. 2004. Peningkatan Profesionalisme Guru Sekolah Dasar. Jakarta: Bumi Askara. \\
\hline 5 & Nurdin, S. 2002. Guru Profesional dan Implementasi Kurikulum. Jakarta: Ciputat Pers \\
\hline & $\begin{array}{l}\text { Saputra, U. 2013. Pengembangan Kinerja Guru. } \\
\text { http://uharsputra.wordpress.com/pendidikan/pengembangan-kinerja-guru/. Diakses pada } \\
\text { Tanggal 29 November 2020 }\end{array}$ \\
\hline 7 & $\begin{array}{l}\text { Fathurrohman, M. 2012. Implementasi Manajemen Peningkatan Mutu Pendidikan Islam. } \\
\text { Yogyakarta: Teras. }\end{array}$ \\
\hline 8 & Sudirman, A.M. 2006. Interaksi dan Motivasi Belajar Mengajar. Jakarta: Raja Grafindo. \\
\hline 10 & $\begin{array}{l}\text { Majid, A. 2007. Perencanaan Pembelajaran: Mengembangkan Standar Potensi Guru. Bandung: } \\
\text { Rosda Karya. }\end{array}$ \\
\hline 11 & Salam, A. 2014. Manajemen Insani dalam Pendidikan. Yogyakarta: Pustaka Pelajar. \\
\hline 12 & $\begin{array}{l}\text { Hendra, H. 2010. Perencanaan Sistem Pembelajaran: Kurikulum Tingkat Satuan Pendidikan. } \\
\text { Curup: LP2 STAIN. }\end{array}$ \\
\hline 13 & $\begin{array}{l}\text { Hamalik, O. 2003. Perencanaan Pembelajaran Berdasarkan Pendekatan Sistem. Jakarta: Bumi } \\
\text { Aksara. }\end{array}$ \\
\hline 14 & Mulyasa, E. 2004. Menjadi Kepala Sekolah Profesional. Bandung: Remaja Rosda Karya. \\
\hline
\end{tabular}

